OPEN ACCESS

E-ISSN : 2549-6581

Artikel Hasil Penelitian

Diterima : 2 April 2017

Direview : 5 April 2017

Dimuat : April-Juli 2017
Journal of Issues in Midvifery

\title{
FAKTOR-FAKTOR YANG MEMPENGARUHI KETERLAMBATAN PERKEMBANGAN ANAK USIA 1-3 TAHUN DI DESA CANGKRINGSARI KECAMATAN SUKODONO KABUPETEN SIDOARJO
}

\author{
Astri Poborini ${ }^{1}$, , Maulidha $^{1}$, Dewi Larasati ${ }^{1}$ \\ ${ }^{1}$ Midwifery Departement, Faculty of Medicine, Universitas Brawijaya \\ Email: ap rini@ymail.com \\ HP +6281266279792
}

\begin{abstract}
Preschoolers are children aged 3-5 years who come with many potentials. Motor development is a developing process of body motion control that includes central and peripheral nerves activity, and the muscles as well. Motor development can be categorized into two categories: gross motor and fine motor development. Every child will undergo these two development processes. In preschool age, motor development increases rapidly from $50 \%$ to $80 \%$. Behavioral stimulation is one of the factors which may affect child's motor development. Children who get targeted and regular stimulation have faster progress than children who are less/not stimulated. This study aimed to identify the correlation between behavioral stimulation and the motor development of prescoolers using DDST (Denver Development Screening Test) assessment form in PAUD (Early Childhood Education) Kasih Bunda, Kotalama Sub-district, Kedungkandang District, Malang. The design of this study was observational analytic using cross-sectional approach. Purposive sampling method was used with the total respondents of 63 children. The data obtained were analysed using non-parametric statistical analysis with Likelihood Ratio untilobtained a significant result on fine motor development variable $\alpha=0.00$; while the same analysis technique obtained $\alpha=0.055$ on gross motor development variable. It can be concluded that there is a
\end{abstract}


correlation between behavioral stimulation and preschoolers fine motor development, but there is no correlation between stimulation-giving behavior and preschoolers gross motor development in PAUD (Early Childhood Education) Kasih Bunda, Kotalama Sub-district, Kedungkandang District, Malang.

Keywords: Preschooler, behavioral stimulation, motor development

\section{ABSTRAK}

Anak prasekolah adalah anak berusia 3-5 tahun yang memiliki berbagai macam potensi. Perkembangan motorik merupakan proses perkembangan kontrol gerak tubuh melalui koordinasi aktivitas saraf pusat, saraf tepi, dan otot. Perkembangan motorik dibagi menjadi dua: perkembangan motorik kasar dan perkembangan motorik halus. Setiap anak akan mengalami kedua proses perkembangan ini. Pada anak prasekolah, perkembangan motorik akan berkembang pesat dari $50 \%$ menjadi $80 \%$. Perilaku pemberian stimulasi merupakan salah satu faktor yang dapat mempengaruhi perkembangan motorik anak. Anak yang mendapatkan stimulasi terarah dan teratur akan lebih cepat berkembang dibandingkan dengan anak yang kurang/tidak mendapat stimulasi. Penelitian ini bertujuan untuk mengidentifikasi hubungan perilaku pemberian stimulasi dengan perkembangan motorik pada anak usia prasekolah (3-5 tahun) dengan menggunakan lembar DDST II (Denver Development Screening Test) di PAUD Kasih Bunda Kelurahan Kotalama, Kecamatan Kedungkandang, Kota Malang. Penelitian ini menggunakan desain observasional analitik dengan pendekatan cross sectional. Metode pengambilan sampel menggunakan teknik purposive sampling dengan jumlah responden penelitian sebanyak 63 anak. Hasil uji analisis statistik nonparametrik dengan Likelihood Ratio pada perkembangan motorik halus didapatkan nilai signifikansi $\alpha=0,00$; sedangkan pada perkembangan motorik kasar didapatkan nilai signifikansi $\alpha=0,055$. Kesimpulan penelitian ini adalah terdapat hubungan antara perilaku pemberian stimulasi dengan perkembangan motorik halus, dan tidak terdapat hubungan antara perilaku pemberian stimulasi dengan perkembangan motorik kasar pada anak usia prasekolah (3-5 tahun) di PAUD Kasih Bunda Kelurahan Kotalama, Kecamatan Kedungkandang, Kota Malang. Kata Kunci : Anak prasekolah, perilaku pemberian stimulasi, perkembangan motorik

*Korespondensi: Astri Proborini. Surel: ap rini@ymail.com 


\section{PENDAHULUAN}

Kemampuan orangtua dalam deteksi

dini

gangguan

perkembangan anak, terutama di daerah pedesaan masih relatif rendah. Hal ini dibuktikan dengan masih banyak orangtua yang tidak mengetahui kelainan yang terjadi pada anak, terutama menyangkut gangguan perkembangan anak seperti gangguan bicara dan bahasa, retardasi mental yang berkaitan dengan gangguan bahasa, motorik kasar, motorik halus, kecerdasan dan autisme. Rendahnya kemampuan orangtua dalam deteksi dini, mengakibatkan orangtua sering ter-lambat memeriksakan atau berkonsultasi dengan dokter atau para medis lainnya. ${ }^{1}$ Masalah lain yang terjadi adalah masih banyak orangtua yang beranggapan bahwa perkembangan keterampilan motorik pada anak dapat berjalan dengan sendirinya. ${ }^{2}$

Pada tahun 2007, 35,4\% anak di Indonesia menderita penyimpangan dalam motorik kasar, motorik halus, serta penyimpangan mental emosional. ${ }^{3}$ lkatan Dokter Anak Indonesia (IDAI) Jawa Timur juga melakukan pemeriksaan terhadap 2.634 anak usia 0-72 bulan. Hasil pemeriksaan perkembangan tersebut ditemukan data normal sesuai dengan usia sebesar 53\%, meragukan (membutuhkan pemeriksaan lebih dalam) sebanyak 13\%, dan penyimpangan perkembangan sebanyak 34\%. Dari hasil data penyimpangan perkembangan, 10\% adalah motorik kasar, dan 30\% motorik halus. Berdasarkan data di atas terlihat bahwa angka meragukan dan penyimpangan perkembangan masih cukup besar di Indonesia. ${ }^{4}$

Pemerintah Indonesia telah menggalakkan sebuah program untuk kesehatan anak balita. Program tersebut bernama Stimulasi Deteksi dan Intervensi Dini Tumbuh Kembang Balita yang dilakukan minimal dua kali dalam setahun pada anak balita usia 12-59 bulan yang harus dipantau secara berkelanjutan untuk memastikan kesehatan mereka selalu dalam kondisi optimal. ${ }^{5}$ Selain program tersebut, pemerintah Indonesia juga bekerja sama pihak UNICEF dalam mengembangkan sebuah kerangka kebijakan yang komprehensif untuk 
mengimplementasikan komponenkomponen yang saling berkaitan dengan Pendidikan Anak Usia Dini (PAUD). Salah satu komponen tersebut adalah stimulasi pada anak. $^{6}$

Pada beberapa aspek perkembangan seperti kognitif, fisik, motorik, dan psikososial seorang anak berkembang secara pesat dari $50 \%$ menjadi $80 \%$ pada saat prasekolah. ${ }^{7}$ Salah satu aspek penting pada proses perkembangan anak pada usia prasekolah adalah perkembangan motorik, karena perkembangan motorik merupakan awal kecerdasan dan emosi sosial anak. $^{8}$

Keterlambatan motorik dapat menyebabkan anak merasa rendah diri, kecemburuan terhadap anak lain, kekecewaan terhadap sikap orangtua, penolakan sosial, ketergantungan dan malu. ${ }^{9}$ Oleh karena itu, stimulasi ini harus diberikan secara rutin dan berkesinambungan dengan kasih sayang, metode bermain dan lainlain, sehingga perkembangan anak dapat berjalan secara optimal. ${ }^{10}$ Aktivitas orangtua dalam memberikan stimulasi ini merupakan salah satu contoh perilaku orangtua dalam melatih perkembangan anak. ${ }^{11}$ Perilaku merupakan hasil dari segala macam pengalaman serta interaksi manusia dengan lingkungannya yang terwujud dalam bentuk pengetahuan, sikap dan tindakan. ${ }^{12}$

Berdasarkan studi pendahuluan yang telah dilakukan di TK AISYIYAH 20 Kecamatan Kedungkandang pada bulan Mei 2016, dengan jumlah responden sebanyak 15 orang ibu yang memiliki anak usia prasekolah (3-5 tahun), didapatkan hasil bahwa ibu yang memiliki perilaku pemberian stimulasi kurang sebanyak 5 orang, cukup sebanyak 6 orang, dan baik sebanyak 4 orang. Sedangkan pada observasi perkembangan motorik anak, didapatkan hasil bahwa terdapat suspect pada motorik halus dan motorik kasar sebanyak sebanyak 3 orang, suspect pada motorik kasar dan normal pada motorik halus sebanyak 3 orang, suspect pada motorik halus dan normal pada motorik kasar sebanyak 1 orang, serta normal pada motorik kasar dan motorik halus sebanyak 8 orang.Tujuan dari 
penelitian ini untuk mengetahui adanya hubungan perilaku pemberian stimulasi dengan perkembangan motorik pada anak usia prasekolah (3-5 tahun) dengan menggunakan lembar DDST II (Denver Development Screening Test) di PAUD Kasih Bunda Kelurahan Kotalama, Kecamatan Kedungkandang, Kota Malang.

\section{METODE}

\section{Rancangan/Desain Penelitian}

Desain penelitian yang digunakan adalah observasional analitik dengan pendekatan cross sectional.

\section{Sumber Data}

Variabel independen dalam penelitian ini adalah perilaku pemberian stimulasi, dan variabel dependen adalah perkembangan motorik pada anak usia prasekolah (3-5 tahun)..

\section{Sasaran Penelitian}

Jumlah sampel sebanyak 63 anak prasekolah yang berusia 3-5 tahun dan ibunya yang dipilih dengan teknik purposive sampling.

\section{Pengembangan Instrumen dan}

Teknik Pengumpulan Data

Instrumen yang digunakan dalam penelitian ini berupa kuesioner perilaku pemberian stimulasi dan lembar observasi DDST II (Denver Development Screening Test). Dalam uji validitas kuesioner perilaku pemberian stimulasi, didapatkan 16 pertanyaan yang memiliki nilai $r$ hitung $>$ dari $r$ tabel dengan nilai signifikansi (Sig. $(2$-tailed) $)<0.05$ (rtabel $=0.514)$. Sedangkan dalam uji reabilitas kuesioner didapatkan nilai Cronbach's Alpha sebesar 0,955. Karena nilai Cronbach's Alpha>0.6 maka instrumen yang digunakan dinyatakan reliabel.

\section{Teknik Analisis Data}

Data yang telah terkumpul ini, kemudian dianalisa menggunakan Uji Likelihood Ratio untuk melihat hubungan antara perilaku pemberian stimulasi dengan perkembangan motorik pada anak usia prasekolah (3-5 tahun). Dikatakan terdapat hubungan jika nilai signifikan $\alpha<0,05$. 
HASIL PENELITIAN

Karakteristik Umum

Tabel 1 Distribusi Karakteristik

Responden lbu dan Murid

PAUD Kasih Bunda Kelurahan Kotalama, Kecamatan

Kedungkandang, Kota Malang

\begin{tabular}{|c|c|c|}
\hline $\begin{array}{c}\text { Karakteristik } \\
\text { responden }\end{array}$ & $\mathbf{N}$ & $\%$ \\
\hline \multicolumn{3}{|l|}{ Karakteristik ibu } \\
\hline \multicolumn{3}{|l|}{ a. Usia ibu } \\
\hline -15-25 tahun & 16 & 25 \\
\hline -26-35 tahun & 34 & 54 \\
\hline -36-45 tahun & 13 & 21 \\
\hline -46-50 tahun & 0 & 0 \\
\hline$\cdot>50$ tahun & 0 & 0 \\
\hline \multicolumn{3}{|l|}{ b. Pendidikan terakhir } \\
\hline ibu & 14 & 22 \\
\hline - SD & 21 & 33 \\
\hline - SMP/MTsN & 28 & 45 \\
\hline - SMA/MAN/SMK & 0 & 0 \\
\hline -D1/D2/D3 & 0 & 0 \\
\hline \multicolumn{3}{|l|}{ - S1/S2/S3 } \\
\hline \multicolumn{3}{|l|}{ c. Pekerjaan ibu } \\
\hline -Wiraswasta & 12 & 19 \\
\hline • Karyawan & 11 & 17 \\
\hline - Tidak bekerja/IRT & 40 & 64 \\
\hline - Lain-lain & 0 & 0 \\
\hline \multicolumn{3}{|l|}{ d. Pendapatan } \\
\hline perbulan orangtua & $\begin{array}{c}3 \\
15\end{array}$ & 5 \\
\hline • $\leq$ Rp. 500.000 & 15 & 24 \\
\hline Rp.500.000- & 31 & 49 \\
\hline Rp.1.000.000 & 10 & 16 \\
\hline $\begin{array}{l}\cdot>\quad \text { Rp.1.000.000- } \\
\text { Rp.2.000.000 }\end{array}$ & 4 & 6 \\
\hline - > Rp.2.000.000- & & \\
\hline Rp.3.000.000 & & \\
\hline - > Rp.3.000.000 & & \\
\hline \multicolumn{3}{|l|}{ Karakteristik anak } \\
\hline \multicolumn{3}{|l|}{ a. Usia anak } \\
\hline •3tahun & 11 & 18 \\
\hline - 4 tahun & 43 & 68 \\
\hline - 5 tahun & 9 & 14 \\
\hline
\end{tabular}

\begin{tabular}{lcc}
\hline $\begin{array}{l}\text { b. Jenis kelamin anak } \\
\text { - Laki-laki }\end{array}$ & 23 & 37 \\
- Perempuan & 40 & 63 \\
\hline $\begin{array}{l}\text { c. Urutan anak } \\
\text { - Ke-1 }\end{array}$ & 24 & 38 \\
- Ke-2 & 24 & 38 \\
- Ke-3 & 11 & 17 \\
- Ke-4 & 3 & 5 \\
-Ke-5 & 0 & 0 \\
-Ke-6 & 1 & 2 \\
\hline
\end{tabular}

d. Jumlah saudara

- 0 orang $10 \quad 16$

- 1 orang $23 \quad 36$

- 2 orang $12 \quad 19$

- 3 orang 1321

-4 orang 58

Berdasarkan tabel 1 di atas

dapat diketahui bahwa sebagian besar ibu berusia 26-35 tahun sebanyak 34 responden (54\%), berpendidikan terakhir

SMA/MAN/SMK sebanyak 28 responden (45\%), bekerja sebagai ibu rumah tangga (tidak bekerja) sebanyak 40 responden (64\%), dan berpendapatan perbulan >Rp.1.000.000-Rp.2.000.000 sebanyak 31 responden (49\%). Selain itu didapatkan sebagian besar anak berusia 4 tahun sebanyak 43 responden (68\%), berjenis kelamin perempuan sebanyak 40 responden (63\%), urutan ke-1 dan ke-2 sebanyak 24 responden $(38 \%)$, dan berjumlah saudara 1 orang sebanyak 23 responden (36\%). 


\section{Perilaku Pemberian Stimulasi}

Tabel 2 Distribusi Perilaku

Pemberian Stimulasi lbu di PAUD Kasih Bunda Kelurahan Kotalama, Kecamatan

Kedungkandang, Kota Malang

\begin{tabular}{lcc}
\hline $\begin{array}{c}\text { Perilaku } \\
\text { pemberian } \\
\text { stimulasi }\end{array}$ & $\mathbf{N}$ & $\%$ \\
\hline Kurang & 23 & 37 \\
\hline Cukup & 31 & 49 \\
\hline Baik & 9 & 14 \\
\hline Total & 63 & 100 \\
\hline \multicolumn{3}{c}{ Berdasarkan tabel 2 di atas }
\end{tabular}

dapat disimpulkan bahwa 31 dari 63 responden (49\%) memiliki perilaku pemberian stimulasi kategori cukup.

\section{Perkembangan Motorik}

Tabel 3Distribusi Perkembangan Motorik Halus dan Kasar

Pada Anak Usia Prasekolah

(3-5 tahun) di PAUD Kasih Bunda Kelura- han Kotalama,

Kecamatan Kedungkandang, Kota Malang

\begin{tabular}{lcc}
\hline $\begin{array}{l}\text { Perkembangan } \\
\text { Motorik }\end{array}$ & $\mathbf{N}$ & $\mathbf{\%}$ \\
\hline $\begin{array}{l}\text { Motorik Halus } \\
\text { Usia } 3 \text { tahun } \\
\text { - Normal }\end{array}$ & 8 & 73 \\
- Suspect & 2 & 18 \\
- Untestable & 1 & 9 \\
Usia 4 tahun & & \\
- Normal & 29 & 68 \\
- Suspect & 13 & 30 \\
- Untestable & 1 & 2 \\
Usia 5 tahun & 7 & 78 \\
- Normal & 2 & 22 \\
\hline
\end{tabular}

\begin{tabular}{lcc}
\hline $\begin{array}{l}\text { - Suspect } \\
\text { - Untestable }\end{array}$ & 0 & 0 \\
\hline $\begin{array}{l}\text { Motorik Kasar } \\
\text { Usia 3 tahun } \\
\text { - Normal }\end{array}$ & & \\
- Suspect & 2 & 73 \\
- Untestable & 1 & 9 \\
$\begin{array}{l}\text { Usia 4 tahun } \\
\text { - Normal }\end{array}$ & 34 & 79 \\
- Suspect & 8 & 19 \\
- Untestable & 1 & 2 \\
Usia 5 tahun & & \\
- Normal & 9 & 100 \\
- Suspect & 0 & 0 \\
- Untestable & 0 & 0 \\
\hline \multicolumn{2}{c}{ Berdasarkan tabel 3 di atas }
\end{tabular}

dapat disimpulkan bahwa sebagian besar anak prasekolah yang berusia 3, 4, dan 5 tahun perkembangan motorik halusnnya adalah normal.Pekembangan motorik normal pada anak usia 3 tahun sebanyak 8 responden (73\%), pada usia 4 tahun sebanyak 29 responden (68\%), dan pada usia 5 tahun sebanyak 7 responden (78\%). Sedangkan pada perkembangan motorik kasar, sebagian besar anak prasekolah yang berusia 3,4 , dan 5 tahun memiliki perkembangan motorik kasar yang normal. Perkembangan motorik kasar yang normal pada anak usia 3 tahun sebanyak 8 responden (73\%), pada usia 4 tahun sebanyak 34 rresponden $(79 \%)$, dan pada usia 5 tahun sebanyak 9 resonden (100\%). 
Hubungan Perilaku Pemberian

Stimulasi Dengan Perkembangan

Motorik Pada Anak Usia

Prasekolah (3-5 Tahun)

Tabel 4 Analisis Hubungan Perilaku Pemberian Stimulasi Dengan

Perkembangan Motorik Halus

Pada Anak Usia Prasekolah (3-5

Tahun) di PAUD Kasih Bunda

Kelura- han Kotalama,

Kecamatan Kedung-

kandang, Kota Malang

motorik halus. Sebanyak 23 responden memiliki perilaku pemberian stimulasi kategori kurang, 7 responden $(11,1 \%)$ diantaranya memiliki anak dengan perkembangan motorik halus yang normal, 15 responden (23,8\%) memiliki anak dengan suspect pada perkembangan motorik halus, dan 1 responden $(1,6 \%)$ sisanya memiliki anak dengan untestable pada perkembangan motorik halus. Sebanyak 9 responden memiliki

\begin{tabular}{|c|c|c|c|c|c|c|c|c|}
\hline \multirow{3}{*}{$\begin{array}{c}\text { Perilaku } \\
\text { Pember } \\
\text { ian } \\
\text { Stimula } \\
\text { si }\end{array}$} & \multicolumn{6}{|c|}{$\begin{array}{l}\text { Perkembangan Motorik } \\
\text { Halus }\end{array}$} & \multirow{3}{*}{$\begin{array}{l}\text { Tot } \\
\text { al }\end{array}$} & perNajiku pemberian stimula \\
\hline & \multicolumn{2}{|c|}{ Normal } & \multicolumn{2}{|c|}{ Suspect } & \multicolumn{2}{|c|}{$\begin{array}{c}\text { Untes- } \\
\text { table }\end{array}$} & & $\%$ kat@gri baik, 8 responden (12, \\
\hline & $\mathrm{N}$ & $\%$ & $\mathrm{~N}$ & $\%$ & $\mathrm{~N}$ & $\%$ & & \\
\hline urar & 7 & $\begin{array}{c}11 \\
1\end{array}$ & 1 & 8 & & 1. & 23 & mbangan mot \\
\hline & & 46, & 2 & 3,2 & & 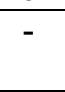 & & memiliki anak den \\
\hline Balk & 8 & $\begin{array}{r}12 \\
7 \\
\end{array}$ & & & 1 & 1, & 9 & 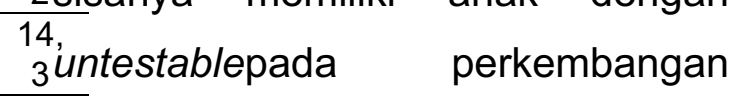 \\
\hline & & & & & 2 & 3, & & tori \\
\hline
\end{tabular}
Berdasarkan tabel 4 di atas dapat disimpulkan bahwa sebagian besar responden memiliki perilaku pemberian stimulasi kategori cukup sebanyak 31 responden dengan 29 responden $(46 \%)$ diantaranya memiliki anak dengan perkembangan motorik halus yang normal, dan 2 responden sisanya $(3,2 \%)$ memiliki anak dengan suspect pada perkembangan Berdasarkan uji statistik dengan menggunakan Likelihood Ratio diperoleh nilai signifikan sebesar $0,00 \quad(\alpha<0,05) \quad$ yang menunjukan bahwa terdapat hubungan yang signifikan antara perilaku pemberian stimulasi dengan perkembangan motorik halus. Nilai signifikan 0,00 artinya semakin baik perilaku pemberian stimulasi yang dilakukan oleh ibu, 
maka tingkat perkembangan motorik halus yang ditunjukkan cenderung normal.Hasil uji statistik diperoleh $p=0,00$ yang berarti $\mathrm{H}_{0}$ ditolak dan $\mathrm{H}_{\mathrm{a}}$ diterima artinya bahwa terdapat hubungan yang signifikan antara perilaku pemberian stimulasi dengan perkembangan motorik halus anak usia prasekolah (3-5 tahun).

Tabel 5 Analisis Hubungan Perilaku Pemberian Stimulasi Dengan Perkembangan Motorik Kasar

Pada Anak Usia Prasekolah (3-5

Tahun) di PAUD Kasih Bunda

Kelurahan Kotalama,

Kecamatan Kedungkandang, Kota Malang

\begin{tabular}{|c|c|c|c|c|c|c|c|c|c|}
\hline \multirow{3}{*}{$\begin{array}{l}\text { Perilaku } \\
\text { Pemberi } \\
\text { an } \\
\text { Stimulasi }\end{array}$} & \multicolumn{6}{|c|}{ Perkembangan Motorik Halus } & \multirow{3}{*}{$\begin{array}{c}\text { Tot } \\
\text { al }\end{array}$} & \multirow{3}{*}{$\%$} & \multirow{3}{*}{$\begin{array}{c}\text { Nilai } \\
\text { Sig } \\
\text { nifik } \\
\text { ansi } \\
\alpha\end{array}$} \\
\hline & \multicolumn{2}{|c|}{ Normal } & \multicolumn{2}{|c|}{ Suspect } & \multicolumn{2}{|c|}{$\begin{array}{c}\text { Untes } \\
\text { table }\end{array}$} & & & \\
\hline & $\mathrm{N}$ & $\%$ & $\mathrm{~N}$ & $\%$ & $\mathrm{~N}$ & $\%$ & & & \\
\hline Kurang & 15 & 23,8 & 7 & 11,1 & 1 & $\begin{array}{l}1, \\
6\end{array}$ & 23 & 36,5 & $\begin{array}{c}0,05 \\
5\end{array}$ \\
\hline Cukup & 29 & 46,0 & 2 & 3,2 & - & - & 31 & 49,2 & \\
\hline Baik & 7 & 11,1 & 1 & 1,6 & 1 & $\begin{array}{l}1, \\
6\end{array}$ & 9 & 14,3 & \\
\hline Total & 51 & 81,0 & 10 & 15,9 & 2 & $\begin{array}{l}3, \\
2\end{array}$ & 63 & 100 & \\
\hline
\end{tabular}

Berdasarkan tabel 5 di atas dapat disimpulkan bahwa sebagian besar responden memiliki perilaku pemberian stimulasi kategori cukup sebanyak 31 responden dengan 29 responden (46\%) diantaranya memiliki anak dengan perkembangan motorik kasar yang normal, dan 2 responden sisanya $(3,2 \%)$ memiliki anak dengan suspect pada perkembangan motorik kasar. Sebanyak 23 responden memiliki perilaku pemberian stimulasi kategori kurang, 15 responden (23,8\%) diantaranya memiliki anak dengan perkembangan motorik kasar yang normal, 7 responden $(11,1 \%)$ memiliki anak dengan suspect pada perkembangan motorik kasar, dan 1 responden $(1,6 \%)$ sisanya memiliki anak dengan untestable pada perkembangan motorik kasar. Sebanyak 9 responden memiliki perilaku pemberian stimulasi kategori baik, 7 responden $(11,1 \%)$ diantaranya memiliki anak dengan perkembangan motorik kasar yang normal, 1 resonden (1,6\%) memiliki anak dengan suspect pada perkembangan motorik kasar dan 1 responden $(1,6 \%)$ sisanya memiliki anak dengan untestablepada perkembangan motorik kasar.

Berdasarkan uji statistik dengan menggunakan Likelihood Ratio diperoleh nilai signifikan sebesar $0,055(\alpha>0,05)$ yang menun-jukan bahwa tidak terdapat hubungan yang signifikan antara perilaku 
pemberian stimulasi dengan perkembangan motorik kasar. Hasil uji statistik diperoleh $p=0,055$ yang berarti $\mathrm{H}_{0}$ diterima dan $\mathrm{H}_{a}$ ditolak artinya bahwa tidak terdapat hubungan yang signifikan antara perilaku pemberian stimulasi dengan perkembangan motorik kasar anak usia prasekolah (3-5 tahun).

\section{PEMBAHASAN}

\section{Perilaku Pemberian Stimulasi}

Hasil penelitian mengenai perilaku pemberian stimulasi terhadap 63 orang ibu didapatkan bahwa sebanyak 31 responden $(49,2 \%)$ memiliki perilaku pemberian stimulasi yang cukup, sebanyak 9 responden $(14,3 \%)$ memiliki perilaku pemberian stimulasi yang baik, dan sebanyak 23 responden (36,5\%) memiliki perilaku pemberian stimulasi yang kurang.

Hasil yang diperoleh peneliti sesuai dengan penelitian yang dilakukan oleh Nabela (2013) yang berjudul profil pengetahuan, sikap, dan perilaku ibu dalam stimulasi perkembangan dan hubungannya dengan perkembangan kognitif anak prasekolah yang mendapatkan hasil bahwa perilaku stimulasi ibu sebagian besar adalah baik $(62,50 \%) .{ }^{13}$ Hasil penelitian ini sesuai, karena pada hasil tabulasi silang peneliti didapatkan responden yang memiliki perilaku pemberian stimulasi tingkat baik berpendidikan SMA, SMP, dan SD yang masing-masing berjumlah 3 responden $(4,76 \% \%)$, sedangkan perilaku pemberian stimulasi tingkat cukup sebagian besar didapatkan pada ibu yang berpendidikan SMA sebesar 16 responden (25,4\%). Pada penelitian Nabela (2013), sebagian besar responden yang memiliki perilaku stimulasi tingkat baik didapatkan pada ibu yang berpendidikan $\mathrm{S} 1$ yaitu sebesar 21 responden $(32,8 \%){ }^{13}$

Hal ini sesuai dengan pernyataan Hidayat (2006) bahwa pendidikan dan pengetahuan orangtua sangat berpengaruh terhadap pemberian stimulasi, karena dengan pendidikan dan pengetahuan yang semakin tinggi, orangtua dapat mengarahkan anak sedini mungkin dan akan mempengaruhi daya pikir anak untuk berimajinasi. ${ }^{14}$ Latar belakang 
keluarga yang mendukung juga mempengaruhi prestasi anak. ${ }^{15}$

Perkembangan anak dapat berlangsung sesuai tahapan usianya baik melalui stimulasi langsung dari orangtua, melalui alat permainan, anggota keluarga lain, sosialisasi anak dengan orang dewasa maupun teman sebaya di lingkungan tempat tinggal. ${ }^{16}$ Penelitian yang dilakukan oleh Barros dkk di Brazil dengan Batelle's Developmentlnventory untuk menilai perkembangan, mendapatkan hasil bahwa anakanak yang mendapatkan stimulasi nilainya lebih tinggi dan kemampuan perkembangannya lebih baik daripada anak yang tidak

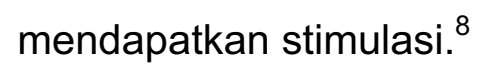

Perkembangan Motorik

Perkembangan Motorik Halus Anak Usia Prasekolah (3-5 tahun) Hasil penelitian menunjukkan sebagian besar anak usia prasekolah (3-5 tahun) memiliki perkembangan motorik halus yang normal sebanyak 44 responden (69,8\%), suspect sebanyak 17 responden $(27 \%)$, dan untestable sebanyak 2 responden (3,2\%). Perkembangan motorik halus adalah gerakan yang menggunakan otot-otot halus atau sebagian anggota tubuh tertentu yang dipengaruhi oleh kesempatan untuk belajar dan berlatih. ${ }^{17}$

$$
\text { Pada penelitian ini, }
$$
presentase anak laki-laki dengan diagnosa normal memiliki presentase lebih besar dibandingkan anak perempuan, dengan perbandingan $82,61 \%$ dan $62,5 \%$. Hal tersebut sesuai dengan pernyataan

Soetjiningsih (2015)bahwa anak laki-laki cenderung memiliki sifat agresif dibandingkan anak perempuan. Kecenderungan ini menjadikan anak laki-laki lebih sering mengekspresikan diri secara terbuka tanpa rasa takut dan salah. Perbedaan potensi dan kecenderungan sifat yang dimiliki antara anak laki-laki dan perempuan terjadi karena perbedaan perkembangan fisik dan psikis yang terjadi antara keduanya. Perbedaan ini tentu berpengaruh pada kemampuan anak laki-laki dan anak perempuan dalam perkembangannya. Anak laki-laki perkembangan akademisnya akan 
lebih baik dan lebih aktif dari pada anak perempuan. ${ }^{18}$

Berdasarkan urutan anak dalam keluarga, sebagian besar perkembangan motorik halus yang normal didapatkan pada anak pertama yaitu sebanyak 18 responden (28,57\%). Hal ini didukung oleh pernyataan Yanti (2011) bahwa anak pertama cendurung memiliki perkembangan yang bagus karena mereka dituntut untuk lebih mandiri.Anak pertama didorong untuk mencapai standar sangat tinggi oleh orangtua sehingga orangtua cenderung lebih memperhatikan anak pertama. ${ }^{19}$

Sementara itu uji Marginal Homogeneity pada variabel luar lain seperti umur ibu, tingkat pendidikan dan status pekerjaan tidak memberikan hasil yang signifikan $(p>0,05)$, yang berarti variabelvariabel tersebut secara statistika tidak mempunyai hubungan yang bermakna dengan perkembangan motorik halus anak. ${ }^{20}$ Studi perkembangan anak di Pakistan juga memberikan hasil bahwa tidak ada perbedaan yang signifikan antara ibu yang bekerja dan tidak bekerja terhadap perkembangan anak. $^{21}$

\section{Perkembangan Motorik Kasar Anak Usia Prasekolah (3-5 tahun)}

Hasil penelitian menunjukkan sebagian besar anak usia prasekolah (3-5 tahun) memiliki perkembangan motorik kasar yang normal sebanyak 51 responden (81\%), suspect sebanyak 10 responden $(15,9 \%)$, dan untestable sebanyak 2 responden (3,2\%). Perkembangan motorik kasar adalah aktivitas anak dengan menggunakan otot-otot besar yang meliputi gerak dasar lokomotor, non lokomotor dan manipulative. ${ }^{22}$

Pada penelitian ini, presentase anak laki-laki dengan diagnosa normal memiliki presentase lebih besar dibandingkan anak perempuan, dengan perbandingan $86,96 \%$ dan $77,5 \%$. Hal tersebut sesuai dengan pernyataan Soetjiningsih (2015)bahwa anak laki-laki cenderung memiliki sifat agresif dibandingkan anak perempuan. Kecenderungan ini menjadikan anak laki-laki lebih sering mengekspresikan diri secara terbuka tanpa rasa takut dan salah. 
Perbedaan potensi dan
kecenderungan sifat yang dimiliki
antara anak laki-laki dan perempuan
terjadi karena perbedaan
perkembangan fisik dan psikis yang
terjadi antara keduanya. Perbedaan
ini tentu berpengaruh pada kemampuan anak laki-laki dan anak perempuan dalam perkembangannya. Anak laki-laki perkembangan akademisnya akan lebih baik dan lebih aktif dari pada anak perempuan. ${ }^{18}$

Pada penelitian ini sebagian besar perkembangan motorik kasar yang normal didapatkan pada anak kedua yaitu sebanyak 19 responden $(30,16 \%)$. Hal ini didukung oleh pernyataan menurut Hidayat (2006) bahwa posisi anak dalam keluarga dapat mempengaruhi perkembangannya. Pada anak pertama,anak akan cenderung memilikikemampuan intelektual lebih menonjol dan cepat berkembang karena sering berinteraksi dengan orang-orang di sekitarnya. Namun pada aspek motorik anak justru kadang mengalami keterlambatan, hal ini dikarenakan kurangnya pengalamaan yang dimiliki oleh ibudalam mengasuh anaknya termasuk pemberian stimulasi. Sedangkan pada anak kedua dan seterusnya orangtua cenderung merasa sudah biasa dalam merawat anaknya dan lebih percaya diri sehingga kemampuan anak untuk beradaptasi lebih cepat dan mudah meskipun perkembangan intelektual biasanya kurang apabila dibandingkan dengan anak pertama, kecenderungan juga bergantung pada keluarga(kurang percaya diri). ${ }^{14}$

Sementara itu uji Marginal Homogeneity pada variabel luar lain seperti umur ibu, tingkat pendidikan dan status pekerjaan tidak memberikan hasil yang signifikan ( $p$ $>0,05)$ yang berarti variabelvariabel tersebut secara statistika tidak mempunyai hubungan yang bermakna dengan perkembangan motorik kasar anak. ${ }^{20}$ Studi perkembangan anak di Pakistan memberikan hasil bahwa tidak ada perbedaan yang signifikan antara ibu yang bekerja dan tidak bekerja terhadap perkembangan anak. ${ }^{21}$

Hubungan Perilaku Pemberian Stimulasi Dengan Perkembangan 
Motorik Halus Pada Anak Usia Prasekolah (3-5 tahun)

Hasil analisis hubungan perilaku pemberian stimulasi dengan perkembangan motorik halus pada anak usia prasekolah didapatkan nilai signifikansi dari uji Likelihood Ratio sebesar 0,00 $<\alpha=0,05$. Artinya apabila ibu memiliki perilaku pemberian stimulasi tingkat baik atau cukup, maka perkembangan motorik halus anak lebih cenderung ke arah normal. Sedangkan bila diuji menggunakan Spearman Correlation didapatkan hasil bahwa besarnya pengaruh perilaku pemberian stimulasi terhadap perkembangan motorik halus sebesar $31 \%$ dengan nilai Spearman Correlation sebesar 0,556 . Hal ini tentu memberikan kontribusi yang cukup besar dikarenakan banyak faktor lain yang dapat mempengaruhi perkembangan motorik halus anak, misalnya lingkungan.

Selain faktor perilaku pemberian stimulasi, faktor lain yang dapat mempengaruhi perkembangan motorik halus yaitu faktor lingkungan. Hal ini dibuktikan saat di sekolah anak diajarkan untuk menggambar, menulis, dan mewarnai.

Sehingga, perkembangan motorik halus anak dapat terlatih. ${ }^{16}$ Kartini Kartono (1995:21) menambahkan faktor yang dapat mempengaruhi perkembangan motorik halus anak yaitu hereditas dan aktivitas anak sebagai subyek yang bebas yang berkemauan, kemampuan, punya emosi serta mempunyai usaha untuk membangun diri sendiri. ${ }^{23}$

Tahapan perkembangan motorik halus pada masing-masing anak berbeda, ada anak yang tidak dapat menulis tetapi dapat membaca. Menurut Erikson dalam Wong (2001) anak usia prasekolah masih belajar dalam mengendalikan diri dan memanipulasi lingkungan, rasa inisiatif mulai menguasai anak, anak lebih cenderung menuntut melakukan tugas tertentu, misalnya merapikan tempat tidur, dan merapikan mainannya. Hal ini menyebabkan perkembangan motorik halus setiap anak berbeda, yaitu sesuai dengan apa yang diinginan dan inisiatifnya. ${ }^{24}$

Meskipun peran ibu dalam pemenuhan kebutuhan dasar anak baik, tetapi masih terdapat 
perkembangan motorik halus anak yang belum tercapai. Hal ini dibuktikan dengan masih ada anakanak yang gagal dalam memenuhi standar tugas yang ditentukan. Misalnya pada saat menyusun balok-balok menjadi suatu bangunan, kadang-kadang anak meruntuhkan sendiri balok tersebut karena kurang konsentrasi, tidak dapat menggambar orang dengan 3 bagian, dan membuat bentuk persegi. Pada usia 4-5 tahun koordinasi gerakan motorik halus anak sudah baik, hal ini dibuktikan dengan mampunya anak dalam mengkoordinasikan gerakan visual motorik, seperti mengkoordinasikan gerakan mata dengan tangan, lengan, dan tubuh secara bersamaan, antara lain dapat dilihat pada waktu anak menulis atau menggambar.

Hubungan Perilaku Pemberian Stimulasi Dengan Perkembangan Motorik Kasar Pada Anak Usia Prasekolah (3-5 tahun)

Hasil analisis hubungan
perilaku pemberian stimulasi
dengan perkembangan motorik
kasar pada anak usia prasekolah
didapatkan nilai signifikansi dari uji

Likelihood Ratio sebesar 0,055 $>\alpha=0,05$. Nilai signifikansi $\alpha=0,055$ menunjukkan bahwa tidak terdapat hubungan antara perilaku pemberian stimulasi dengan perkembangan motorik kasar anak usia prasekolah (3-5 tahun). Artinya tidak ada pengaruh antara ibu yang memiliki perilaku pemberian stimulasi yang baik/cukup/kurang terhadap perkembangan motorik kasar anak yang normal/suspect/untestable.

Sedangkan bila diuji menggunakan Spearman Correlation didapatkan hasil bahwa besarnya pengaruh perilaku pemberian stimulasi terhadap perkembangan motorik kasar sebesar $4,58 \%$ dengan nilai Spearman Correlation sebesar 0,214 . Pada presentase ini didapatkan hubungan namun sangat lemah.

Distribusi perkembangan motorik kasar yang normal pada penelitian ini terlihat tidak merata antara ibu yang memiliki perilaku pemberian stimulasi baik dengan yang kurang, karena perkembangan motorik kasar yang dihasilkan sebagian besar tidak terdapat perbedaan yang signifikan yaitu 
sama-sama hasilnya normal. Hal ini dikarenakan dalam memberikan stimulasi motorik kasar pada anak usia prasekolah ini relatif sederhana dan mudah dilakukan. Tingginya jumlah perilaku pemberian stimulasi yang kurangpada perkembangan motorik kasardisebabkan karena banyaknya ibu yang berpendapat bahwa kegiatan menendang bola, melempar dan berlari itu sudah cukup dilakukan dengan temantemannya tanpa harus ibu melatihnya. Pernyataan tersebut bertolak belakang dengan Santrock (2007) yang menyatakan bahwa kemajuan perkembangan akan lebih efektif, terkoordinasi, dan terkendali apabila mendapatkan instruksi, interaksi dan dukungan dari orang dewasa di sekitar mereka tinggal. ${ }^{8}$

Pada dasarnya anak-anak prasekolah mengalami kemajuan yang besar dalam ketrampilan motorik kasar (gross motor skill), seperti berlari, melompat, yang melibatkan penggunaan otot besar. Perkembangan daerah sensoris dan motoris pada korteks memungkinkan koordinasi yang lebih baik antara apa yang diinginkan oleh anak dan apa yang dapat dilakukannya pada anak prasekolah. Tulang dan otot mereka semakin kuat, dan kapasitas paru mereka semakin besar memungkinkan mereka untuk berlari, melompat, dan memanjat lebih cepat, lebih jauh, dan lebih baik seiring bertambahnya usia. ${ }^{25}$

Pada penelitian ini sebagian besar didapatkan anak memiliki perkembangan motorik kasar yang normal meskipun dengan perilaku pemberian stimulasi yang kurang. Hal ini disebabkan karena ketrampilan motorik kasar akan berkembang lebih dulu daripada motorik halus, jika keterampilan motorik kasar anak kurang baik, maka akan mempengaruhi saraf otak yang dapat menyebabkan kemandirian dan aktivitas anak akan terlambat. Namun hal itu juga berdampak pada perkembangan anak yang lain seperti halnya perkembangan motorik halus, aktivitas sosial, kemampuan konsentrasi, dan kemampuan motor planning yang juga akan kurang baik. $^{26}$ Dari pernyataan ini dapat disimpulkan bahwa anak akan lebih cenderung menguasai atau memiliki ketrampilan pada aspek motorik 
kasar dibandingankan dengan motorik halus.

Perkembangan motorik kasar pada anak usia prasekolah berbeda-beda, beberapa anak ada yang mengalami perkembangan yang lebih, ini dibuktikan anak yang berusia 4 tahun mampu melakukan akivitas berdiri satu kaki selama 8 detik dan berjalan dengan tumit kaki diangkat (jinjit) yang seharusnya dilakukan anak berusia 5-6 tahun. Anak yang berusia 4 tahun, mereka memanjat tangga dengan tangkas, sedangkan anak anak yang berusia $5-6$ tahun mereka lebih suka melakukan kompetisi dengan teman sebaya seperti berlari cepat, bermain bola walaupun tidak akan mendapat medali, tetapi aktivitas tersebut merupakan

suatu kebanggaan. ${ }^{27}$ Namun tidak jarang juga anak dapat mengalami keterlambatan pada aspek ini.Bahaya penyebab terlambatnya perkembangan motorik, sebagian dapat dikendalikan dan sebagian lagi tidak. Terlambatnya pekembangan motorik kasar dapat disebabkan oleh gangguan organis di otak yang berupa dispraxia (gangguan di pusat-pusat tertentu yang mengalami kesulitan meski sudah terlatih). ${ }^{28}$ Penyebab lainnya yaitu kurangnya kesempatan anak untuk mempelajari ketrampilan motorik, perlindungan orangtua yang berlebihan atau kurangnya motivasi anak untuk mempelajarinya dan kurangnya stimulasi. ${ }^{29}$

\section{SIMPULAN}

Terdapat hubungan antara perilaku pemberian stimulasi dengan perkembangan motorik halus pada anak usia prasekolah (3-5 tahun) di PAUD Kasih Bunda Kelurahan Kotalama, Kecamatan Kedungkandang, Kota Malang dan tidak terdapat hubungan antara perilaku pemberian stimulasi dengan perkembangan motorik kasar pada anak usia prasekolah (35 tahun) di PAUD Kasih Bunda

\section{DAFTAR PUSTAKA}

1. Soetjiningsih. Buku Ajar Tumbuh Kembang Remaja dan Permasalahannya. Jakarta: Sagung Seto. 2007.

2. Ertem, O. I. et al. Mothers' Knowledge of Young Child Development A Developing 
Country. Journal Compilation, Vol 33, No.6. 2007; p. 728-737.

3. Soedjatmiko. Peranan TPA Dalam Upaya Pembinaan Tumbuh-Kembang Anak Dalam Buku Ajar 2 Tumbuh Kembang Anak Dan Remaja Edisi 1. Jakarta: Sagung Seto. 2008.

4. Nadhiroh, F. Deteksi Tumbuh Kembang Anak Pecahkan Rekor Muri. Online [WWW]. http://surabaya.detik.com/read/20 07/08/05/161244/813430/475/det eksi-tumbuhkembang-anakpecahkan-rekor-muri. [accessed 15 March 2016].

5. Kementerian Kesehatan RI. Profil Kesehatan Indonesia Tahun 2013. Jakarta: Kementerian Kesehatan RI. 2014.

6. Keamey, Angela. Indonesia Laporan Tahunan 2012.Online [WWW]. 2012.

http://www.unicef.org/indonesia/id IUNICEF Annual Report (Ind) 1 30731.pdf. [accessed 15 June 2016].

7. Kemendiknas RI. Pedoman Teknis Penyelenggaraan Taman Penitipan Anak.Jakarta:

Direktorat Jenderal Pendidikan Non formal dan Informal. 2010.
8. Santrock, J. W.Life-Span Development: Perkembangan Masa Hidup. Achmad Chusairi \& Juda Damanik (penerjemah). Jakarta: Erlangga. 2007.

9. Hurlock, E. B. Psikologi Perkembangan. Jakarta: Erlangga. 2006.

10. Dinkes. Profil Kementerian Kesehatan Indonesia Pusat dan Surveilans Epydemiologi

Profil Kesehatan Indonesia. Jakarta: Kementerian RI. 2009.

11. Notoatmodjo, S. Promosi Kesehatan dan IImu Perilaku.Jakarta: Rineka Cipta. 2007.

12. Sarwono S. Sosiologi Kesehatan. Jakarta: Rineka Cipta. 2004.

13. Nabela, Narulita. Profil Pengetahuan, Sikap, Dan Perilaku Ibu Dalam Stimulasi Perkembangan Dan Hubungannya Dengan Perkembangan Kognitif Anak Prasekolah Di KB-TK Selaras Cita Malang. Skripsi. Tidak diterbitkan. Fakultas Kedokteran Universitas Brawijaya Malang. Malang.2013. 
14. Hidayat, Alimul. Pengantar IImu Keperawatan Anak. Jakarta: Salemba Medika. 2006.

15. Ladd, G. W., Birch, S. H., \& Buhs, E. S. Children's Social And Scholastic Lives In Kindergarten: Related spheres of influence. Child Development, 70. 2008; p.1373-1400.

16. Ariyana, D. \& Rini, N. S. Hubungan Pengetahuan lbu Tentang Perkembangan Anak Dengan Perkembangan Motorik Kasar Dan Halus Anak Usia 3-5 Tahun di TK Bustanul Atfal 7 Semarang. Jurnal Keperawatan Vol 2. 2009; p. 11-20.

17. Harlimsyah. Aspek-Aspek Pertumbuhan dan

Perkembangan. Jakarta: EGC. 2007.

18. Soetjiningsih. Tumbuh Kembang Anak.Jakarta: EGC. 2015.

19. Yanti, Etri dkk. Hubungan Stimulasi Terhadap Perkembangan Motorik Halus Anak Prasekolah Usia (3-5 Tahun) Di Paud Almubaraqah Ampang Kecamatan Kuranji Tahun 2011.STIKes
Padang.Online

[WWW]. 2011.http://journal.mercubaktijaya ac.id/downlotfile.php?file=7.pdf. [accessed 25 November 2016].

20. Kusuma, Irawan Fajar, dkk. Hubungan Pengetahuan lbu Tentang Stimulasi Dini Dengan Perkembangan Motorik Pada Anak Usia 6-24 Bulan di Kecamatan Mayang Kabupaten Jember. Jurnal IKESMA Volume 9 Nomor 1 Maret 2013. Bagian IImu Kesehatan Masyarakat Fakultas Kedokteran Universitas Jember.2013.

21. Almani, Abdul S., et al. Study of the Effects of Working Mothers on the Development of Children in Pakistan. International Journal of Humanity and Social Science Vol 2 (11). 2012; p. 164 $-171$.

22. Samsudin. Pengembangan Motorik di Taman Kanak Kanak. Jakarta: Fakultas IImu Keolahragaan Universitas Negeri Jakarta. 2005. 23.

24. Kartono, Kartini. Psikologi Anak (Psikologi Perkembangan). Bandung: Mandar Maju. 1995. 
25. Wong, D. L.et al. Buku Ajar Keperawatan Pediatrik Edisi 6 Tahun 2001.Agus Sutarna, Neti Juniarti \& H. Y. Kuncara (penerjemah). Jakarta: EGC. 2009.

26. Papalia, dkk. Human Development, Perkembangan Manusia. Jakarta: Salemba Humanika. 2008.

27. Irwan. Perkembangan Motorik Kasar. Online [WWW]. 2008.

http://dokteranakku.com/?p=84. [accessed 05 December 2016].

28. Yulia, A. Working Mom and Kids. Jakarta: Elex Media Komputindo. 2007.

29. Tedjasaputra, Mayke S. Bermain, Mainan dan Permainan untuk Pendidikan Anak Usia Dini. Jakarta: Grasindo. 2001.

30. Hurlock, E. B. Perkembangan Anak. Jakarta: Erlangga. 2000. 
Journal of Issues in Midwifery, April - Juli 2017, Vol. 1 No. 1, 51-70 
Journal of Issues in Midwifery, Agustus - November 2017, Vol. 1 No. 2, 1-18 